\title{
UPAYA PENYELAMATAN DIRI DALAM KONDISI DARURAT DI GEDUNG BERTINGKAT I FASILITAS UMUM DITINJAU DARI KEBERADAAN SARANA NAVIGASI KOGNITIF DAN SELF EFFICACY
}

\author{
Tristiadi Ardi Ardani, \\ Andik Rony Irawan, \\ Aris Yuana Yusuf, \\ Zainul Arifin \\ Fakultas Psikologi \\ Universitas Islam Negeri (UIN) Maulana Malik Ibrahim Malang \\ Jl. Gajayana 50 Malang Telp. 0341-558916
}

\begin{abstract}
Abstrak - Kondisi darurat dapat mengancam keselamatan jiwa setiap saat, misalnya kebakaran, gempa bumi, kerusuhan, dan sebagainya. Struktur bangunan yang didesain dengan berbagai antisipasi bencana atau kondisi kondisi darurat serta sarana penyelamatan diri dalam kondisi darurat belum menjamin keselamatan jiwa pengunjung. Fasilitas yang tersedia untuk mengantisipasi kondisi darurat belum sepenuhnya berfungsi secara optimal karena belum tersedianya system informasi yang memadai tentang strategi penyelamatan diri. Informasi yang diberikan hanya bersifat teknis dan managerial sehingga penyelamatan diri pengunjung dalam berbagai peristiwa kerusuhan, kebakaran,dan gempa bumi beberapa waktu yang lalu masih banyak menelan korban jiwa. Penelitian ini merupakan penelitian eksperimental dengan menggunakan desain factorial. Desain ini dipilih karena terdapat empat kelompok yang mendapat perlakuan yang berbeda.Populasi penelitian adalah mahasiswa / mahasiswi yang ada di Kota Malang.Sampel penelitian adalah bagian dari populasi yang diselidiki (Hadi, 1993). Sampel penelitian yang akan digunakan adalah mahasiswa Universitas Islam Negeri (UIN) Maliki Malang sebanyak 52 orang yang diambil secara random. Berdasarkan temuan dilapangan tidak ada perbedaan upaya penyelamatan diri ditinjau dari keberdaan sarana navigasi kognitif dan self efficacy. Tidak terdapat perbedaan upaya penyelamatan diri dalam kondisi darurat di gedung bertingkat ditinjau dari keberdaan sarana navigasi kognitif. Hal ini tidak terbukti sesuai dengan hasil analisis menunjukkan $\mathrm{F}=0.306 \mathrm{sing}=0.503$. Tidak terdapat perbedaan upaya penyelamatan diri dalam kondisi darurat di gedung bertingkat ditinjau dari Self Efficacy. Hal ini tidak terbukti sesuai dengan hasil analisis menunjukkan $F=1.916$ sing $=0.172$
\end{abstract}

Kata kunci: Upaya Penyelamatan Diri, Sarana Navigasi Kognitif, Dan Self Efficacy

PSIKOISLAMIKA. Jurnal Psikologi Islam (JPI) copyright @ 2013 Laboratorium Penelitian, Kajian Psikologi Islam dan Penerbitan. Volume 10. Nomor 1, Tahun 2013

\section{PENDAHULUAN}

Era modernisasi mendorong tersedianya fasilitas yang lengkap dan kemudahan dalam berbagai aspek. Pesatnya perkembangan tata kota dan urbansasi membuat lahan perkotaan semakin sempit sehinga memicu pengembangan fasilitas umum dengan model gedung bertingkat.
Gedung bertingkat banyak digunakan sebagai tempat fasilitas umum. Fasilitas umum merupakan suatu fasilitas yang terbuka dan banyak dimanfaatkan oleh masyarakat untuk menjalankan aktifitas sehari hari, misalnya kampus, rumah sakit, perkantoran, mall dan sebagainya. Fasilitas umum mayoritas dikunjungi banyak orang dengan berbagai golongan 
dan usia. Kenyamanan dan jaminan keselamatan pengunjung merupakan salah satu hal penting harus diperhatikan oleh fihak instansi atau perusahaan. Beberapa fasilitas umum telah dilengkapi dengan: 1) loket infomasi yang petugasnya dapat membantu pengunjung untuk mencari lokasi toko/ ruangan/ layanan /acara yang diperlukan, 2) petugas satpam yang menjaga keamanan dan kenyamanan mall, 3) berbagai fasilitas wajib bagi bangunan public untuk keselamatan saat terjadi kondisi darurat, seperti pintu-pintu darurat, detector asap, dan saluran pipa hydrant baik didalam maupun di luar gedung, 4) beberapa gedung bertingkat dan mall telah dilengkapi dengan peta ADS. Beberapa gedung bertingkat juga dipersiapkan dengan struktur bangunan yang bisa mengantisipasi bahaya yang mengancam misalnya bangunan tahan gempa, tahan api dalam beberapa jam serta penangkal petir. Struktur bangunan juga memenuhi spesifikasi bangunan gedung bertingkat yang bertujuan untuk fasilitas umumdengan berbagai fasilitas untuk mengantisipasi kondisi darurat.

Kondisi darurat dapat mengancam keselamatan jiwa setiap saat, misalnya kebakaran, gempa bumi, kerusuhan, dan sebagainya. Struktur bangunan yang didesain dengan berbagai antisipasi bencana atau kondisi kondisi darurat serta sarana penyelamatan diri dalam kondisi darurat belum menjamin keselamatan jiwa pengunjung. Fasilitas yang tersedia untuk mengantisipasi kondisi darurat belum sepenuhnya berfungsi secara optimal karena belum tersedianya system informasi yang memadai tentang strategi penyelamatan diri. Informasi yang diberikan hanya bersifat teknis dan managerial sehingga penyelamatan diri pengunjung dalam berbagai peristiwa kerusuhan, kebakaran, dan gempa bumi beberapa waktu yang lalu masih banyak menelan korban jiwa. Banyaknya korban jiwa pada saat terjadi kerusuhan, kebakaran, dan gempa bumi beberapa waktu yang lalu dikarenakan pengunjung kesulitan untuk mencari jalan keluar. Pengunjung akan lebih mudah mencari jalan keluar dengan mengetahui peta lokasi dimana pengunjung berada dengan menggunakan peta ADS (ada di sini).

Beberapa gedung bertingkat dan fasiltas umum ada yang dilengkapi dengan peta ADS (ada di sini) dan ada yang tidak dilengkapi dengan peta ADS meskipun sarana lain untuk evakuasi dalam kondisi darurat sudah tersedia. Sugianto (2008) menyatakan bahwa peta ADS sangat membantu pengunjung dalam pencarian jalan keluar jika terjadi kondisi darurat. Ketersediaan peta ADS belum sepenuhnya membantu individu dalam upaya penyelamatan diri dalam kondisi darurat secara maximal karena dipengaruhi individu dalam menggunakan fungsifungsi kognitifnya terutama pengamatan, persepsi, berfikir, dan pengambilan keputusan.

Manusia memiliki kemampuan melakukan representasi mental terorganisir atas lingkungan dimana ia berada yang dikenal sebagai peta kognitif. Greene dkk (1996) mendefinisikan peta kognitif sebagai kerangka mental yang mengikat beberapa representasi untuk mengorganisasikan spasial atas suatu lingkungan fisik. Peta kognitif disimpan sebagai bayangan, atau sebagai preposisi dan bisa keduanya. Proses menggunakan informasi spasial yang tersimpan bersama dengan peta atau alat bantu sejenis dikenal dengan pencarian jalan, dalam prosesnya melibatkan landmark, mengingat kembali dan peta spasial. Pencarian jalan merupakan fungsi adaptif yang memugkinkan seseorang untuk bergerak pada suatu lingkungan secara efisien untuk menempatkan item-item penting dalam lingkungan tersebut. Upaya lain yang menyampaikan informasi spasial juga dapat meningkatkan kemampuan pencarian jalan.

Peta ADS membantu individu dalam pencarian jalan keluar dengan penunjuk arah utara sebagai porosnya, sehingga pengunjung yang mengalami kebingungan akan mudah untuk berfikir dan mencari strategi yang tepat dalam usaha penyelamatan diri. Strategi penyelamatan diri dalam kondisi darurat sangat penting dimiliki pengunjung dengan mengoptimalkan kemampuan kognitif.

Disamping fasilitas yang lengkap untuk pengamanan serta upaya penyelamatan diri juga diperlukan pengoptimalan kemampuan kognitif yang baik, proses penyelamatan diri tidak terlepas dari keyakinan diri individu untuk mencari jalan keluar terhadap bahaya yang mengancam. Individu dengan keyakinan diri (self efficacy) tinggi cenderung memiliki kecemasan rendah (Musfirah, 2003:37-46). Individu yang memiliki kecemasan rendah cenderung lebih tenang dalam menghadapi sesuatu kondisi darurat dan cenderung lebih rasional dalam memikirkan strategi yang tepat untuk menyelamatkan diri terlepas dari keberadaan sarana navigasi kognitif yang ada.

Beranjak pada dasar pemikiran diatas, maka permasalahan yang akan dikaji secara mendalam pada penelitian ini adalah perbedaan upaya penyelamatan diri dalam kondisi darurat ditinjau dari keberadaan sarana navigasi kognitif dan self efficacy. 


\section{PERUMUSAN MASALAH}

Berdasarkan uraian diatas maka dapat dirumuskan permasalahan sebagai berikut:

1. Belum optimalnya penggunaan kemampuan kognitif individu dalam menghadapi kondisi darurat di gedung bertingkat/fasilitas umum sehingga kesulitan dalam upaya menyusun strategi penyelamatan diri terutama bangunan gedung bertingkat yang tidak dilengkapi dengan peta ADS.

2. Ketersediaan fasilitas umum yang dilengkapi dengan fasilitas penyelamatan diri belum menjamin keselamatan jiwa pengunjung karena pengunjung memiliki self efficacy yang rendah. Self efficacy tentang keselamatan diri dalam kondisi darurat yang rendah menjadi tinggi tingkat kecemasannya, dan gugup sehinga sulit untuk memikirkan upaya yang baik untuk menyelamatkan diri. Perlu diketahui bahwasanya kondisi darurat yang mengancam secara otomatis membuat pengunjung cemas dan gugup. Dengan demikian self efficacy sangat berpengaruh dalam upaya penyelamatan diri.

3. Apakah ada perbedaan upaya penyelamatan diri dalam kondisi darurat ditinjau dari keberadaan sarana navigasi kognitif dan self efficacy

4. Apakah aspek-aspek psikologis telah dipertimbangkan dalam pemanfaatan sarana navigasi kognitif sebagai usaha penyelamatan diri dalam kondisi darurat

\section{TUJUAN PENELITIAN}

Secara umum penelitian ini diharapkan mampu membawa manfaat baik praktis maupun teoritis. Secara praktis, Memberikan tambahan khasanah dan model upaya penyelamatan diri, bagi sebuah instansi atau lembaga, perusahaan yang peduli keselamatan dan kenyamanan pengunjung. Manfaat praktis yang kedua adalah, sebagai bekal pengetahuan pengunjung jika dalam kondisi darurat di gedung bertingkat/ fasilitas umum sehingga bisa meminimalkan korban jiwa. Secara teoritis, memberikan tambahan kajian tentang upaya penyelamatan diri terhadap kondisi darurat. Sumbangan terhadap Psikologi Kognitif yang bisa dimanfaatkan pada bidang Psikologi Rekayasa, Psikologi Industri dan Organisasi.

\section{KERANGKA KERJA TEORI DAN PENGUJIAN HIPOTESIS}

\section{Deskripsi Teoritik}

\section{Pengertian Upaya Penyelamatan Diri Dalam kondisi Darurat}

Upaya penyelamatan diri adalah usaha untuk menyelamatkan diri dalam kondisi darurat dengan cara paling tepat dan cepat sehingga terlepas dari bahaya yang mengancam. Upaya penyelamatan diri merupakan upaya penyelamatan terhadap diri baik dalam hal financial, kondisi psikologis, sosial, sprirtual dari segala hal yang mengancam dan dapat mengganggu kesehatan kenyamanann dan keselamatan jiwa yang disebabkan oleh kelalaian, kecelakaan, ketidaknyamanan, serta musibah yang terjadi secara tiba-tiba (http//en. wikipedia. org/wiki. safety). Keadaan darurat dapat meliputi banyak hal seperti jatuh sakit mendadak, kebakaran, kecelakaan ditempat kerja, tabrakan dijalan raya, gempa bumi, banjir besar dan tenggelam dilaut. Karakteristik terpenting dari keadaan darurat adalah ancaman terhadap keselamatan seseorang atau sejumlah orang yang dapat mengakibatkan kematian jika tidak ditangani secara cepat dan benar (Hastarjo, Sugianto, Faturrohman, 1994). Kondisi darurat ini memerlukan upaya penyelamatan diri yang tepat agar tidak jatuh banyak korban jiwa.

Tipe tipe upaya penyelamatan diri terdiri dari 1) nomativ safety yaitu upaya penyelamatan diri dalam produk yang digunakan, artinya waspada terhadap produk-produk yang akan digunakan. 2) substantive safety adalah upaya penyelamatan dan kenyamanan yang sesungguhnya yang diinginkan setiap individu dalam setiap bidang kehidupan. 3) perceived safety adalah kenyamanan atau usaha penyelamatan diri dengan menggunakan sarana penyelamatan diri yang disediakan, contohnya tangga darurat dalam gedung bertingkat (http// en. wikipedia. org/wiki. safety ).

Upaya penyelamatan diri ini merupakan visual examination for angerous situation yaitu upaya penyelamatan diri dalam kondisi darurat disuatu tempat. Kondisi darurat meliputi, kecelakaan, sakit mendadak, gempa bumi, terror bom, dan kerusuhan (http//en. wikipedia. org/wiki. Safety ).

Dengan semakin banyaknya ancaman bahaya teror pada bangunan tinggi, perlu dicari upaya untuk mengevakuasi 5000 orang dalam waktu kurang dari 30 menit tanpa menggunakan tangga atau lift. Juwana J.S ( 2005) menyebutkan bahwa saat ini telah dikembangkan system penyelamatan diri di gedung bertingkat tinggi dengan sabuk 
pengaman yang dikaitkan pada gulungan kabel. Begitu gulungan terkunci pada system inti maka orang dapat melompat dan mendarat ditanah denga selamat. Evakuasi darurat lain yang dapat digunakan adalah menggunakan kantong peluncur (chute system) yang ditempatkan pada ruang tangga, dengan system ini, orang dapat memilih untuk keluar bangunan melalui tangga daurat atau kantong peluncur, chute sytem ini juga dapat digunakan oleh orang cacat untuk dapat mencapai lantai dasar dengan selamat.

\section{Gedung Bertingkat atau Fasilitas Umum}

Gedung bertingkat adalah bangunan karya arsitektur yang dirancang dari pertimbangan, konsep-konsep sitem bangunan (arsitektur, structural, mekanikal dan elektrikal) serta lingkungan sekitar (Juwana, 2005). Dalam merancang gedung bertingkat tinggi, disamping aspek arsitektur, structural, mekanikal dan elektrikal. Keterpaduan diantara system bangunan akan membuat bangunan tersebut bukan saja memiliki keindahan dan dapat digunakan sesuai dengan fungsinya, tetapi juga mau bertahan terhadap beban yang bekerja padanya dan mapu memiiki nilai ekonomis yang dapat dipertanggung jawabkan. Sistem struktur bangunan tinggi harus mampu memikul beban grafitasi, beban angin, dan beban goncangan akibat gempa. Sistem mekanika dan elektrikal meliputi ranspotasi vertical, system tata udara, penanggulangan dan pencegahan bahaya, system pelistrikan dan das item pemipaan.

Bangunan tinggi yang modern diharapkan dapat mendukung kebutuhan manusia yang berada didalam bangunan. Untuk itu di dalam bangunan perlu disediakan segala sesuatu yang dibutuhkan bagi metabolism manusia seperti air yang bersih, pengolahan limbah, pengendalian suhu, kelembaban udara, privasi, keamanan, kenyamananlainnya baik baik yang berkaitan dengan aspek visual maupun pendengaran. Oleh karena itu diperlukan pasokan energy berupa tenaga listrik untuk mengoperasionalkan perlengkapan bangunan baik untuk transportasi, disribusi serta untuk evakuasi dalam kondisi darurat. Bangunan harus kokoh aman terhadap keruntuhan, bahaya api, sambaran peir dan gaya-gaya yang disebabkan oleh angin dan gempa bumi.

Rancangan sebuah bangunan tinggi untuk penggunaa tunggal seperti apartemen, perkantoran, sekolah, dan rumah sakit, ataupun untuk penggunaan ganda untuk berskala besar misalnya unuk mall atau tower, memerlukan pendekatan tim antara berbagai disiplin ilmu perancangan, fabrikasi bahan dan konstruksi bangunan. Pembangnan gedung bertingkat tidak hanya memenuhi tuntutan bentuk tertutup umum dalam gedung bertingkat serta efisien bahan tetapi uga juga harus memenuhi ketentuan lainnya yang berkaitan dengan persyaratan keamanan, kenyamanan, keselamatan dari bahaya yang mengancam (Schuellerr, 2001).

Perancangan gedung bertingkat atau fasilitas umum harus memikirkan system pencegahan dan penanggulangan kondisi darurat (Juwana, 2005). Pencegahan dan penanggulangan kondisi darurat di gedung bertingkat dapat berupa :

a) Sistem pencegahan dan penanggulangan bahaya kebakaran pasif yaitu yang bertumpu pada rancangan bangunan yang memungkinkan orang keluar dari bagunan dengan selamat pada saat terjadi kebakaran atau kondisi darurat lainnya. Sistem penaggulangan kondisi darurat secara pasif meliputi konstruksi tahan api misalnya langit- langit yang dapat mencega perambatan api, koridor dan jalan keluar harus dilengkapi dengan tanda "EXIT" atau "KELUAR" dengan anak panah menunjukan arah menuju pintu keluar terdekat atau tangga darurat dan harus ditempatkan pada setiap lokasi dimana pintu keluar terdekat tidak dapat langsung dilihat serta diberi lampu yang menyala dalam kondis darurat. Kompartemen yaitu menahan dan membatasi penjalaran api agar dapat melindungi manusia atau barang agar tidak tersentuh langsung dengas sumber api. Tangga darurat yang berupa tangga kedap api dan asap yang merupakan tempat yang paling aman dan harus bebas dari gas panas dan beracun. Pengendalian asap dengan memasang tirai penghalang asap, pengalaman menunjukkan bahwa ruang yang luas seperti pusat perbelanjaan, mall bioskop dan ruang pertemuan berpeluang untuk menghasilkan asap.

b) Sistem pencegahan dan penanggulangan bahaya kebakaran aktif dapat berupa alat pengindraan atau peringatan dini (detector) yaitu detector asap dan panas akan memberikan peringatan dini, hidran dan selang kebakaran, sprinkler, pasokan air yang berupa tangki air tekanan air.

c) Sistem tanda bahaya atau alarm. Secara umum system tanda bahaya ada dua yaitu tanda bahaya dalam kondisi darurat terkai pada keamanan bangunan dan yang terkait dengan keamanan penghuni dan harta benda 
yan ditujukan untuk menangkal kejahatan.

d) Sistem penangkal petir, pada prinsipnya menydiakan jalur menerus dari logam yang menyalurkan petir ke tanah pada saat terjadi sambaran petir pada bangunan

\section{Pengertian Sarana Navigasi Kognitif}

Sarana navigasi kognitif merupakan alat yang berfungsi sebagai sarana informasi pada situasi normal, dan alat memandu serta menuntun para pengunjung kearah dan cara yang tepat untuk menyelamatkan diri pada situasi darurat saat mereka sedang pada posisi tertentu. Sarana yang difungsikan sebagai navigasi kognitif disini adalah peta ADS (ada disini) (Sugianto, 2008). Peta ADS mencakup beberapa hal a) denah situasi bangunan dan posisi dia berada, b) posisi pintu-pintu darurat yang terhubung ke tangga-tangga penyelamat, dan c) prosedur baku penyelamatan diri.

Peta ADS sebagai sarana navigasi kognitif dalam memandu pengunjung untuk mencari jalan keluar maka: 1) orientasi penempatan peta ADS dibuat kompatibel dengan ego reference pengunjung, sehingga untuk memahaminya dalam situasi mendesak (darurat) pada saat kebakaran, gempa bumi atau ancaman bom, pengunjung tidak harus melakukan rotasi mental dari peta kognitif (yang menganut orientasi arah utara) ke peta subjektif pengunjung, yang berakibat memperlama proses pemahaman dan pengambilan keputusan pengunjung (Wickens, 1992).

\section{Pengertian Self Efficacy}

Self efficacy adalah keyakinan mengenai sejauh mana individu memperkirakan dirinya dalam melaksanakan suatu tugas atau tindakan yang diperlukan untuk mencapai suatu hasil. Self efficacy sangat penting dalam segala aspek kehidupan selain menurunkan kecemasan dalam kondisi darurat, dengan self efficacy yang tinggi seorang individu akan memiliki keyakinan yang kuat bahwa dirinya akan berhasil dalam melaksanakan suatu tugas tertentu sehingga individu tersebut akan melakukan berbagai strategi untuk bisa menyelamatkan diri.

Pada beberapa dimensi, pengharapan individu terhadap self-eficacy dalam dirinya bisa berbedabeda dan memberikan manifestasi yang cukup berarti pada perasaan dan perilakuindividu yang pada akhirnya akan berimplikasi pada kinerja. Bandura (dalam Harjanto, 1997) menyebutkan dimensi-dimensi tersebut adalah:

a) Magnitude, berkaitan degan tingkat kesulitan yang dilakukan

b) Generality, berkaitan dengan luas bidang yang dilakukan

c) Strenght, berkaitan dengan kemantapan atau tingkat keyakinan individu

\section{Riset Terdahulu}

Riset Terdahulu Tentang Upaya Penyelamatan Diri Dalam Kondisi Darurat

O' Neill (1992) meneliti upaya penyelamatan diri dengan pencarian jalan keluar pada gedung yang sebelumnya sudah familiar. Sedangkan Raubal M (dalam sugianto, 2008) telah meneliti tentang upaya penyelamatan diri dengan pencarian jalan keluar pada gedung yang lokasinya tidak familiar

Penelitian tentang upaya penyelamatan diri pada kondisi darurat yang melibatkan kemampuan kognitif telah dilakukan oleh Malinowski, J.C (2001), Golledge (1996b). Kemampuan kognitif yang terlibat meliputi kemampuan spatial, persepsi dan ingatan. Kemampuan kognitif sangat membantu dalam pengunaan peta lokasi yang ada pada sebuah gedung.

Selanjutnya penelitian tentang upaya penyelamatan diri dalam kondisi darurat yang melibatkan peta lokasi bangunan dilakukan oleh Baldwin (2003). Penelitian mengenai usaha pencarian jalan keluar dengan menggunakan peta digital dilakukan oleh Davies (2002). Pencarian jalan keluar dengan menggunakan peta lokasi sangat membantu dalam usaha penyelamatan pengunjung gedung bertingkat. Kognitif

Riset Terdahulu Tentang Sarana Navigasi

Bhitnnety-Etsem dkk (2007) telah melakukan penelitian tentang sarana navigasi kognitif sebagai upaya peningkatan legibilitas pada bagunan mall atau fasilitas umum. Dalam penelitian tersebut, aspek psikologismengenai persepsi, ingatan berfikir, respond an pengamblan keputusan atas stimulus yang diterima dari lingkungan telah dipertimbangkan secara seksama sebagai pelengkap aspek-aspek teknis dan ekonomis yang telah diterapkan, dalam mengupayakan peningkatan kompabilitas manusia dan teknologi.

Penelitian tentang sarana navigasi kogntif yang berikutnya dilakukan oleh Sugianto dkk (2008). Penelitian ini mengemukakan tentang sarana navigasi kognitif sebagai upaya peningkatan kemudahan evakuasi pada bangunan mall / fasilitas umum. Hasil penelitian tersebut menunjukkan bahwa terdapat perbedaan waktu reaksi pencarian jalan 
keluar antara dua jenis peta yaitu orientasi arah utara dan searah subjek. Sujek rata-rata memiliki kemampuan representasi peta kognitif yang tinggi sehingga dapat diberdayakan untuk keperluan navigasi kognitif.

\section{Riset Terdahulu Tentang Self Efficacy}

Self efficacy telah diteliti sebelumnya oleh Rusmawati dan Widodo (2004) dalam penelitian ini, self efficacy dihubungkan dengan kewirausahaan pada mahasiswa prodi psikologi FK UNDIP Semarang. Hasil penelitian ini menunjukkan bahwa semakin tinggi self efficacy individu maka semakin tinggi pula kewirauhannya.

Tella (2007) meneliti tentang self efficacy dengan penggunaan informasi elektronik sebagai predictor dari akademik kerja. Hasil penelitian menunjukkan bahwa individu yang memiliki self efficacy tinggi dalam menngunakan informasi elektronik maka akan memiliki prestasi akademik yang bagus.

Musfirah (2003) meneliti tentang self efficacy dan kecemasan menggunakan computer. Hasil penelitian menunjukkan bahwa semakin tinggi self efficacy yang dimiliki individu maka semakin rendah tigkat kecemasannya dalam menggunakan komputer.

Berdasarkan penelitian diatas menunjukkan bahwa individu yang memiliki self efficacy yang tinggi akan cenderung memiliki kecemasan yang rendah dan mudah dalam melakukan apa yang dihadapi.

\section{Hipotesis Penelitian}

Menurut Sutrisno Hadi, batasan hipotesis sebagai berikut:

"Dugaan yang mungkin benar,atau mungkin juga salah atau palsu, dan akan diterima jika fakta-fakta membenarkannya. Adapun bertolak dari kondisi di depan maka dapat dikemukakan hipotesis sebagai berikut:

Hipotesis pertama menyatakan terdapat perbedaan upaya penyelamatan diri dalam kondisi darurat di gedung bertingkat ditinjau dari keberadaan sarana navigasi kognitif.

Hipotesis kedua menyatakan terdapat perbedaan upaya penyelamatan diri dalam kondisi darurat di gedung bertingkat ditinjau dari Self Efficacy.

\section{METODOLOGI PENELITIAN}

\section{Tempat dan Waktu Penelitian}

Penelitian ini dilakukan di UIN MALIKI Malang karena di UIN MALIKI Malang juga memiliki gedung bertingkat tinggi. Penelitian dilaksanakan pada tanggal 9 November 2010.

\section{Metode Penelitian}

Penelitian ini merupakan penelitian eksperimental dengan menggunakan desain factorial. Desain faktorial diartikan sebagai desain penelitian dimana terdapat dua variable bebas atau lebih yang saling dihadapkan untuk mengkaji akibat-akibat yang mandiri terhadap suatu variable terikat (Kerlinger, 1993). Desain ini dipilih karena terdapat empat kelompok yang mendapat perlakuan yang berbeda.

\section{Populasi dan Teknik Pengambilan Sampel}

Populasi adalah totalitas dari semua nilai yang mungkin, baik hasil menghitung atau pengukuran (kuantitatif maupun kualitatif) dari suatu karakteristik tertentu mengenai sekumpulan objek yang engkap dan jelas (Sujana, dalam Poerwati 1998). Populasi penelitian adalah mahasiswa / mahasiswi yang ada di kota malang.

Sampel penelitian adalah bagian dari populasi yang diselidiki (Hadi, 1993). Sampel penelitian yang akan digunakan adalah mahasiswa Universitas Islam Negeri (UIN) Maliki Malang yang diambil secara random. Teknik random sering pula disebut dengan random sampling. Teknik random adalah pengambilan sampel yang dilakukan secara acak (random). Cara ini dianggap sebagai cara yang akurat, karena bertitik tolak pada pinsip-prinsip matematika yang kokoh. Cara ini sering pula disebut sebagai rancangan sampel probabilitas, karena penarikan unit-unit sampel mengikuti hukum probabilitas, dimana setiap unit atau anggauta populasi memperoleh kesempatan yang sama untuk dipilih menjadi sampel penelitian. Pemilihan sampel penetian didasarkan pada alasan bahwa pengguna terbanyak gedung bertingkat / fasilitas umum terutama Mall adalah mahasiswa.

Dalam uji coba (try out) peneltian, sampel kurang lebih terdiri dari 75 mahasiswa dan pada saat penelitian sampel berjumlah 52 orang.

\section{Teknik Pengumpulan Data}

\section{Definisi Konstruk}

Jenis data ada dua macam, data primer dan data sekunder. Data primer adalah tanggapan atau jawaban subjek terhadap beberapa aspek permasalahan tentang upaya penyelamatan diri dalam kondisi darurat di gedung bertingkat atau 
fasilitas umum yang dilengkapi dengan sarana navigasi kognitif dan yang tidak dilengkapidengan saran navigasi kognitif. Subjek juga menjawab beberapa pertanyaan tentang keyakinan diri untuk dapat menyelamatkan diri dalam kondisi darurat di gedung bertingkat atau fasilitas umum terlepas ada dan tidaknya sarana avigai kognitif.

Dalam penelitian ini hanya menggunakan data primer, karena jenis penelitiannya adalah eksperimen, jadi pengambilan data secara langsung saat peneliti mengadakan eksperimen.

\section{Definisi operasional Variabel-variabel Penelitian}

Definisi operasional diperlukan karena definisi tersebut akan menunjuk pada alat pengambilan data yang cocok digunakan dan untuk mencegah kesalahpahaman pengertian terhadap data yang dikumpulkan, disamping supaya variabel yang akan dapat dimengerti secara praktis (Suryabrata, 1990).

Adapun definisi operasional variable penelitian ini adalah:

1) Variabel bebas: Sarana navigasi kognitif : peta ADS ( ada di sini ) yang berguna untuk menuntun dan memandu para pengunjung ke arah dan cara yang tepat untuk menyelamatkan diri pada situasi darurat saat mereka sedang berada pada posisi tertentu

Self Efficacy: keyakinan tentang sejauh mana individu memperkirakan dirinya dalammelaksanakan suatu tugas atau tindakan yang diperlukan untuk mencapai suatu hasil

2) Variabel Terikat: Upaya penyelamatan diri dalam kondisi darurat di gedung bertingkat / fasilitas umum adalah usaha untuk menyelamatkan diri dalam kondisi darurat dengan cara paling tepat dan cepat sehingga terlepas dari bahaya yang mengancam.

\section{Kisi-kisi dan Kalibrasi}

Dalam penelitian ini, alat pengukuran atau pengumpulan data terdiri dari:

1) Keberadaan sarana navigasi kognitif

Instrument ini menggunakan slide/ gambar tentang kondisi darurat (kebakaran, gempa bumi, kerusuhan, ancaman bom, kecelakaan mendadak) di suatu gedung bertingkat/ fasilitas umum yang dilengkapi dengan sarana navigasi kognitif dan yang tidak dilengkapi dengan sarana navigasi kognitif. Instrumen ini bias mengungkap tentang kondisi darurat disuatu gedung bertingkat atau fasilitas umum yang dilengkapi dengan sarana navigasi kognitif dan yang tidak dilengkapi dengan sarana navigasi kognitif. Sehingga diharapkan dengan mengetahui visualisasi kondisi darurat tersebut subjek penelitian dapat memikirkan upaya penyelamatan diri yang tepat.

2) Skala upaya penyelamatan diri

Skala upaya penyelamatan diri adalah skala yang digunakan untuk mengungkap upaya penyelamatan diri pengunjung dalam kondisi darurat. Skala upaya penyelamatan diri dalam kondisi darurat dikembangkan berdsarkan kerangka teori visual examination for dangerous situation yaitu kondisi darurat disuatu tempat yang meliputi, kecelakaan, sakit mendadak, gempa bumi, terror bom, dan kerusuhan (http//en. wikipedia. org/wiki. Safety), dan slide atau gambar tentang kondisi darurat (kebakaran, gempa bumi, kerusuhan, ancaman bom, kecelakaan mendadak) di suatu gedung bertingkat/ fasilitas umum yang dilengkapi dengan sarana navigasi kognitif dan yang tidak dilengkapi dengan sarana navigasi kognitif.

3) Skala Self Efficacy

4) Skala self efficacy dalam penelitian ini adalah versi terjemahan dari self efficacy scale HAFA model dari Born A, Schwarzer R, Yerusalem M, (1995) yang terdiri dari 10 item. Langkah ini ditujukan untuk mendapatkan validitas dan reliabilitas alat ukur yang lebih baik dan cermat (http://www.health psych.de).

\section{a. Instrumen Pengukuran Self Efficacy}

Born A, Schwarzer R, Yerusalem M, (1995) telah mengembangkan skala self efficacy yang berupa self efficacy scale HAFA model yang terdiri dari 10 item dengan 4 pilihan jawaban. Alat ukur ini telah diuju cobakan di berbagai Negara dan diperoleh reliabilitas sebesar antara $0.76-0.90$. Tujuan pembuatan item ini adalah untuk mengukur tinggi rendahnya self efficacy individu yang mengalami stress atau yang mengalami kondisi-kondisi darurat.

\section{Instrument Final}

a. Instrumen Pengukuran Upaya Penyelamatan Diri Dalam Kondisi Darurat

Instrument yang digunakan untuk mengukur upaya penyelamatan diri dalam kondisi darurat adalah skala yang disusun berdasarkan upaya penyelamatan diri dalam kondisi darurat disuatu tempat tertentu yang meliputi, kecelakaan, sakit mendadak, gempa bumi, terror bom, dan kerusuhan. (http//en.wikipedia. org/wiki.safety). Skala ini disusun berdasarkan modifikasi Method of Summated 
Rating atau disebut juga dengan Model likert. Skala ini menggunakan lima macam kategori jawaban, yaitu PD : Pasti dilakukan; SD : sering dilakukan; KK : kadang-kadang ; AJD: amat jarang dilakukan; TPD: tidak pernah dilakukan

Pada penelitian ini menggunakan uji coba terpakai, dari 23 item yang digunakan terdapat 6 item yang gugur, item yang gugur ini merupakan item dengan daya beda negatf. Item yang negatif adalah no $(2,14,15,16,18$ dan 23$)$ dengan reliabilitas rxx $=0.68$.

b. Alat Ukur Self Efficacy

c. Pada penelitian ini menggunakan uji coba terpakai, dari 10 item yang digunakan terdapat 1 item yang gugur, item yang gugur ini merupakan item dengan daya dibawah 0.20 . Item yang gugur adalah no ( 2) dengan reliabilitas $\mathrm{rxx}=0.702$

\section{Teknik Analisis Data}

Metode analisis data untuk menguji hipotesis dalam penelitian ini adalah ANALISIS VARIAN 2 JALUR dengan menggunakan progam SPSS Versi 16.

Uji asumsi atau uji prasarat dilakukan sebelum dilakukannya uji hipotesis. Uji asumsi terdiri dari normalitas sebaran dan uji homogenitas. Uji normalitas sebaran dimaksudkan untuk mengetahui apakah data yang akan dianalisis sudah didistribusikan sesuai dengan prinsip-prinsip distribusi normal. Kaidah yang digunakan adalah jika $p>0.05$ maka sebarannya dikatakan normal, dan sebaliknya jika $\mathrm{p}<0.05$ maka sebarannya dikatakan tidak normal (Hadi, 2000). Uji homogenitas varians ini bertujuan untuk mengetahui homogeny tidaknya variable yang digunakan dalam penelitian.

\section{DESKRIPSI DATA DAN PEMBAHASAN}

Deskripsi data penelitian disajikan untuk mengetahui beberapa data pokok yang berkaitan dengan penelitian. Hal yang akan disajikan yaitu: 1) keadaan demografi subjek penelitian, dan 2) rerata empiris dan rerata hipotesis penelitian.

Keadaan Demografik Subjek Penelitian

Data demografik subjek penelitian yang digambarkan meliputi jumlah data yang dianalisis dan jenis kelamin subjek penelitian.

Data yang dianalisis adalah data yang lengkap sesuai hasil pelaksanaan eksperimen dengan perbandingan jumlah data pada masingmasing kelompok perlakuan, disajikan pada tabel berikut.
Tabel: 1

Jumlah Subjek Berdasarkan Perlakuan

\begin{tabular}{|c|c|c|c|c|}
\hline No & Kelompok & Perlakuan & $\begin{array}{c}\text { Jumlah } \\
\text { Subjek }\end{array}$ & Persentase \\
\hline 1 & 1 & 1 & 26 & $50 \%$ \\
\hline 2 & 2 & 2 & 26 & $50 \%$ \\
\hline Total & & & 52 & $100 \%$ \\
\hline
\end{tabular}

Data demografik jenis kelamin subjek penelitian, selengkapnya disajikan dalam tabel berikut.

Tabel : 2

Jenis kelamin Subjek Penelitian

\begin{tabular}{|c|c|c|c|}
\hline No & Jenis Kelamin & Jumlah Subjek & Persentase \\
\hline 1 & Laki-1aki & 5 & $9.615 \%$ \\
\hline 2 & Perempuan & 47 & $90.38 \%$ \\
\hline Total & & 52 & $100 \%$ \\
\hline
\end{tabular}

\section{Rerata Empiris dan Rerata Hipotesis Penelitian}

Rerata empiris dan rerata hipotesis penelitian diperoleh dengan membandingkan skor empiris (skor yang diperoleh) dan skor hipotesis (skor yang dimungkinkan), dari kedua skala dalam penelitian ini, yang mengukur respon subjek berkaitan dengan upaya penyelamatan diri dalam kondisi darurat di gedung bertingkat.

Skor rerata empiris didapatkan dari hasil uji sebaran frekuensi dan histogram, sedangkan rerata hipotesis di peroleh dari rumus sebagai berikut:

$\mathrm{Xh}=\left\{\left(\mathrm{X}_{\mathrm{r}+} \mathrm{Xt}\right) / 2\right\}$

Keterangan:

$\mathrm{X}_{\mathrm{h}=}$ skor rerata empiris

$X_{r=}$ skor terendah pada item skala

$\mathrm{X}_{\mathrm{t}=}$ skor tertinggi pada item skala

Data selengkapnya mengenai rerata empiris upaya penyelamatan diri pada kondisi darurat adalah sebagai berikut:

Tabel: 3

Rerata empiris upaya penyelamatan diri pada kondisi darurat

\begin{tabular}{|c|c|c|c|}
\hline No & Variabel & Rerata empiris & $\begin{array}{c}\text { Rerata } \\
\text { Hipotesis }\end{array}$ \\
\hline 1 & $\begin{array}{c}\text { Upaya penyelamatan } \\
\text { diri pada kondisi } \\
\text { darurat }\end{array}$ & 55.2115 & 77.5 \\
\hline 2 & Self Efficacy & 28.038 & 25 \\
\hline
\end{tabular}

Berdasarkan hasil rerata empiris dan rerata hipotesis dapat diketahui bahwa subjek berkarakteristik baik. 


\section{PENGUJIAN HIPOTESIS \\ Uji Normalitas Sebaran}

Tujuan diadakan uji normalitas sebaran adalah untuk mengetahui apakah data variabel yang diteliti berdistribusi normal atau tidak. Hal ini diperlukan untuk menjawab syarat sampel yang representatif terpenuhi atau tidak sehingga hasil penelitian dapat digeneralisasi pada populasi. Uji normalitas sebaran diuji dengan menggunakan teknik kolmogorovSmirnov Googness of fit Tes SPSS 16. Perhitungan skala upaya penyelamatan diri menunjukka nilai $\mathrm{K} \mathrm{S}-\mathrm{Z}=0.592$ sign $=0.874$. Hal ini menunjukkan bahwa subjek berdistribusi normal

Tabel: $\mathbf{4}$

Uji Normalitas Sebaran

\begin{tabular}{|c|c|c|c|c|c|}
\hline Variabel & Mean & SD & KS-Z & $p$ & Status \\
\hline $\begin{array}{c}\text { Upaya } \\
\text { penyelamatan } \\
\text { diri dalam } \\
\text { kondisi darurat }\end{array}$ & 55.2115 & 7.22560 & 0.592 & 0.874 & Normal \\
\hline
\end{tabular}

\section{Uji Homogenitas Variant}

Homogenitas Varian diuji dengan menggunakan teknik Levene Statistik SPSS 16. Perhitungan skala upaya penyelamatan diri menunjukka nilai $\mathrm{F}=0.124$ $p=0.726$. Hal ini menunjukkan bahwa subjek homogen.

Tabel: 5

Hasil Uji homogenitas

\begin{tabular}{|c|c|c|c|}
\hline Variabel & $F$ & $p$ & Status \\
\hline $\begin{array}{c}\text { Upaya } \\
\text { penyelamatan } \\
\text { diri dalam } \\
\text { kondisi } \\
\text { darurat }\end{array}$ & 0.124 & 0,729 & Homogen \\
\hline
\end{tabular}

\section{Hasil Uji Hipotesis}

Uji Hipotesis ini menggunakan ANAVA 2 Jalur. Hasil analisis tertera dalam tabel berikut

Hasil analisis uji hipotesis dapat diuraikan sebagai berikut:

Hipotesis pertama menyatakan terdapat perbedaan upaya penyelamatan diri dalam kondisi darurat di gedung bertingkat ditinjau dari keberdaan sarana navigasi kognitif. Hal ini tidak terbukti sesuai dengan hasil analisis menunjukkan $\mathrm{F}=0.306$ sing $=0.503$

Hipotesis pertama menyatakan terdapat perbedaan upaya penyelamatan diri dalam kondisi darurat di gedung bertingkat ditinjau dari Self Efficacy. Hal ini tidak terbukti sesuai dengan hasil analisis menunjukkan $\mathrm{F}=1.916$ sing $=0.172$

Hasil analisis menunjukkan bahwa tingkat self efficacy mempunyai nilai rata-rata 50.38

Dari keseluruhan jumlah subjek (52). Skor T dihitung dengan rumus $\mathrm{T}=50+10(\mathrm{M}-\overline{\mathrm{XX}}) / \mathrm{S}$

\section{HASIL DAN PEMBAHASAN}

Berdasarkan temuan dilapangan tidak ada perbedaan upaya penyelamatan diri ditinjau dari keberdaan sarana navigasi kognitif dan self efficacy. Bencana yang sering mengancam negeri ini membuat kita untuk memikirkan alternatif upaya penyelamatan diri yang paling efektif khususnya ketika berda dalam gedung bertingkat/ fasilitas umum. Berdasarkan pengalaman yang lalu banyak terjadi korba meinggal karena terjebak dalam gedung. Pemikira yang pertama adalah dengan menyediakan peta ADS agar mudah untuk mencari jalan keluar sehingga bisa meminimalisir banyaknya jatuh korban jiwa. Berdasarkan temuan di lapangan ternyata keberadaan sarana navigasi kognitif tida berfungsi efektif. Hal ini bisa terjadi karena budaya orang Indonesia yang malas untuk membaca sehingg ada atau tidak ada sarana navigasi kognitif tidak memberikan perbedaan yang berarti dalam upaya penyelamatan diri di gedung bertingkat.

Begitu juga dengan self efficacy yang tinggi pada individu tidak memberikan perbedaan yang berarti dalam upaya penyelamatan diri, budaya indonesia terbiasa dengan gugup bingung dan sebagainya.

Bencana yang sering mengancam negeri ini, yang terbaru gunung meletus dengan didahului gempa tremor dan gempa dengan kekuatan besar maka perlu langkah antisipatif dengan menyosialisasikan dissaster awarenes, berupa pemberian pengetahuan kepada masyarakat untuk tidak sekedar melakukan tindakan reaktif tetapi juga antisipatif dengan memberikan peta ADS, Sinyal tanda bahaya dsb. Hal ini seperti yang dilakukan di jepang (jawa pos, 5 Nov 2010) pemerintah jepang gencar melakukan langkah antisipatif dengan menyosialisasikan dissaster awarenes, berupa pemberian pengetahuan kepada masyarakat untuk tidak sekedar melakukan tindakan reaktif tetapi juga antisipatif yang dirangkum dalam sebuah buku dan setip rumah tangga harus memilkinya.

\section{KESIMPULAN DAN SARAN Kesimpulan}

Tidak terdapat perbedaan upaya penyelamatan diri dalam kondisi darurat di gedung bertingkat ditinjau dari keberdaan sarana navigasi kognitif. $\mathrm{Hal}$ ini tidak terbukti sesuai dengan hasil analisis 
menunjukkan $\mathrm{F}=0.306$ sing $=0.503$

Tidak terdapat perbedaan upaya penyelamatan diri dalam kondisi darurat di gedung bertingkat ditinjau dari Self Efficacy. Hal ini tidak terbukti sesuai dengan hasil analisis menunjukkan $\mathrm{F}=1.916$ sing $=0.172$

\section{Saran Dan Rekomendasi}

Saran, disarankan untuk menyosialisasikan peringatan kondisi darurat kepada masyarakat dengan melakukan tindakan antisipatif berupa tanda-tanda peringatan dini. Pada pengelola gedung bertingkat, untuk melakukan tindakan antisipatif penyelamatan diri dengan menyediakan peta ADS khususnya untuk gedung bertingkat pada gedung kuliah bersama atau Mall . Rekomendasi, Pemberian pengetahuan kepada masyarakat untuk tidak sekedar melakukan tindakan reaktif tetapi juga antisipatif dengan memberikan peta ADS, Sinyal tanda bahaya dsb. Memberikan learning system yang sempurna untuk mengantisipasi bencana berupa keyakinan diri, pengelolaan emosi yang baik dalam kondisi darurat sehingga mudah untuk berfikir jernih.

\section{DAFTAR PUSTAKA}

Azwar. S. 1999. Penyusunan Skala Psikologi. Yogyakarta. Pustaka Pelajar Offset

Baldwin, D, 2003. Wayfinding Technology: A Road Mapto the Future. Journal of Visual Impairment \& Blindness. October

Carmines,E.G and Zeller.1988, Reliability and Validity Series Quantitativ Application in the Social Sciences, England, Sage Publising.

Davies, C ,2002. When is a Map? Task and Language In Spatial Interpretations With Digital Map Displays. Applied Cognitive Psychology, 16: 273-285.

Ergonomics for Managers Back Safety \& Lifting, http//en. wikipedia. org/wiki. Safety (31 Maret 2009)

Golledge,R. Greene.1999. Wayfinding Behaviour : Cognitif Mapping And Other spatial process. Baltimore : Johns Hopkins University press

Golledge, R. Greene.1999b. Precise of Wayfinding Behaviour : Cognitif Mapping And Other spatial process.PSYCOLOQUY, 10 (036)
Hastarjo.T.D, Sugianto, Faturrohman.1994. Sistem Pelayanan Keadaan Darurat. Laporan Penelitian. Fakultas Psikologi UGM.

Hadi, S . 1993. Metodology Research, Jilid 1 .Yogyakarta.Andi offset.

Juwana, J.S. 2005. Panduan sistem Bangunan Tinggi. Jakarta. Erlangga

Kerlinger,F.1996. Azas-azas Penelitian Behavioral,terjemahan. Yogyakarta. Gadjah Mada University press

Musfirah.2003. Hubungan antara Computer Self Efficacy dan Kecemasan Menggunakan Komputer. Psikologika. Jurnal Pemikiran dan Penelitian Psikologi.15.VIII.37-46

Malinowski, J,C. 2001. Mental Rotation And Real World Wayfinding. Perseptual And Motor Skills. Missoula: Feb, Vol.92, Iss.1,p.19.

O'Neil, M. 1992. Effects of Familirity and Plan Complexity on Wayfinding in Simulated Building. Journal of Environmentak Psychology, 12. 319-327.

Ralf, S.Yerussalem. 1995. The General Self Efficacy Scale.http//www.healtpsych.de (26 maret 2009)

Santosa, S. 2003. SPSS Mengolah Data Statistik Secara Profesional. Jakarta. Media Komputindo.

Schuellerr, W. 2001. Struktur Bangunan Bertingkat Tinggi. Bandung. Refika Aditama.

Sugianto.2008. Sarana Navigasi Kognitif Sebagai Upaya Peningkatan Kemudahan Evakuasi Pada Bangunan Mall/Fasum. Jurnal Psikologi UGM. No1.41-61

Suryabrata, S. 1990. Metodologi Penelitian. Jakarta. C.V. Rajawali.

Tella, Omoba, R.O, Ayenni. 2007.Self Efficacy and use of electronic Information as a Predictor of Academic Performance. Electronic Journal of Academic and Special Librarianship.v. 8 no 2 ( Summer 2007). http/ / www. southernlibrarianship. icaap. Org. (31 Maret 2009)

Wickens, C.D.1992. Engineering Psychology And Human Performance $.2^{\text {nd }}$ ed. New York: harpers Collins publisher. 